\title{
Educational quality and dropout risk: a causal analysis of the university dropout phenomenon
}

\section{Inmaculada Pedraza-Navarro ${ }^{1}$, Teresa González-Ramírez ${ }^{2}$}

${ }^{1}$ Education Department, Nebrija University, Spain, ${ }^{2}$ Department of Methods of Research and Diagnostic in Education, University of Seville, Spain.

\begin{abstract}
University dropout is one of the main problems of the Spanish university system due to its high rates. The latest report issued by the Ministry of Science and Innovation (MICINN, 2020) shows that more than 30\% of students drop out of an undergraduate degree program. In order to explore the phenomenon, in line with the scientific literature, we have focused on identifying personal and family variables associated with university dropout. Using an ex post facto, quantitative, descriptive and causal design methodology, we observed significant relationships between the dependent variable "completion of university degree" and the independent variables "age", "marital status" and "number of siblings". In agreement with other researches (Belloc et al, 2010; Diaz Peralta, 2008; Lizarte Simon, 2017) we conclude that university dropout is a multicausal phenomenon that needs to be fully understood. This will allow to maximize the use of resources allocated to higher education and optimize university access, permanence and quality policies.
\end{abstract}

Keywords: Drop-out; higher education; statistical analysis; educational quality. 


\section{Introduction}

The concept of educational quality in higher education has been the subject of numerous analyses and definition proposals. Initially linked to the economic sector, it has been progressively incorporated into the educational sphere due to the imperative need to respond to the problems affecting higher education globally and more specifically in Spain: institutional reforms as a result of the unification of undergraduate and postgraduate curricula driven by the creation of the European Higher Education Area (EHEA); accelerated enrollment growth accompanied by a major expansion of academic offerings; or high university dropout rates that question the success levels of success of the system.

In particular, university dropout, as we conceive it in this contribution, is an expression of how educational quality is managed in each specific context. At the macro level, it has been the subject of numerous reports which repeatedly show that it is a phenomenon that is both relevant and problematic at the global level due to the high rates it presents (AIRef, 20020, MICINN, 2020, OECD 2019). The latest statistics published by Eurostat (2020) point to Malta as the country with the highest university dropout rate, with $18.4 \%$; followed by Spain with $18.3 \%$. In third place is Romania with $18.1 \%$.

These data are worrying, if we take into account that European institutions set the 2020 target of reducing university dropout to $10 \%$. Moreover, the current figures have political, socioeconomic and academic consequences that are felt by students, as well as by the university institution and the State as a whole (Patrick et al., 2016; González-Ramírez and PedrazaNavarro, 2017). This impact has aroused great scientific interest. Various research projects have focused on exploring the phenomenon by identifying its causes and motives. According to Belloc et al. (2010), Diaz Peralta (2008) or Lizarte Simon (2017), university dropout is a multicausal phenomenon that is conditioned by the influence of personal variables and those related to the family and socioeconomic environment of students. The most current research (Behr et al., 2020) call for this problem to be tackled at the micro level, situating the nature of the problem in the specific context in which it occurs and always linked to institutional quality policy, identifying how it is tackled and the singularity of its intervention.

\subsection{Personal, family and socioeconomic variables associated with university dropouts}

Among the personal variables, "sex", "age", "marital status" and "ethnic origin" are crucial. Research indicates that male dropout rates prevail over female dropout rates, despite the fact that the percentage of men enrolled in university is lower (Casquero and Navarro, 2010). Likewise, university dropout mainly affects younger students given their low vocational maturity (Al Ghanboosi and Ayedh, 2013). Although non-traditional students over the age of 25 also drop out of university, as they have the need to allocate part of their time to work and family care (Garcia de Fanelli, 2014). According to Stoessel et al. (2015), combining studies and family care is difficult, which is why married students are at higher risk of dropping out 
of university. In addition, populations composed of ethnic minorities or specific groups, such as the handicapped and high-performance athletes, are at a higher risk of dropout. Belonging to an ethnic group implies a language barrier (with mother tongue different from the official), and discrimination experiencies and prejudice that has negative repercussions on social adaptation (Fonseca and García, 2016).

"Family size", "type of housing", "socio-educational level of parents" and "presence of difficulties" are the most influential family variables. According to Rodríguez Urrego (2019), the greater the number of siblings in the family unit, the greater the risk of abandonment. It also increases the risk when living away from the university, especially, in a home that is not owned (Jara et al., 2008) and outside the family environment (Zanchin, 2017). Remarkably, students' family environment significantly influences their academic life. According to Garbanzo Vargas (2007), a favorable family environment, marked by commitment and democratic coexistence, has an impact on adequate academic performance. Another important element of the family environment is the educational level of the parents. The literature highlights, especially, the educational level of the mother as a relevant variable in this subject. Marchesi (2000) reveals that when mothers' academic level is higher, children perceive greater support for their studies and seek to achieve the goal of graduating. On occasions, the students' trajectory is influenced by the presence of family difficulties that generate discouragement. Despite their low frequency, there are situations such as illness or death of a family member that lead to the decision to abandon university studies (RodríguezPineda and Zamora-Araya, 2020).

The socioeconomic variables include the student's "purchasing power", his or her "employment status", the "way of financing his or her studies", the "lack of economic resources" to cover transportation, tuition, materials, among others, and "family responsibilities" in the "presence of economic difficulties". Conversely, students who come from affluent families are more likely to pass higher education (MDSyF, 2003). It is true that combining studies with work is difficult, since it requires a lot of time dedication. Therefore, the risk of dropout in students who work is higher (Íñiguez et al., 2016). Those students who pay for their studies thanks to financial aid from parents or some financial agency are less likely to drop out (Jones-White et al. 2014; Ononye and Bong, 2018). Unfortunately, changes in personal and family conditions are strongly associated with socioeconomic aspects that influence university dropout. Unexpected situations such as the loss of a job of the breadwinner or the death of the father are factors that prevent students from continuing their university studies, since they are obliged to support their families. 


\section{Methodological research design}

Throughout this research we emphasize the multidimensionality of the phenomenon of university dropout, analyzing the sociological profile of students who dropped out of an undergraduate degree at the Faculty of Education Sciences of the University of Seville. This fact allows us to identify personal and family variables associated with dropping out, a problem that affects $27.8 \%$ of students at the University of Seville. The figure is worrying, even more so when it causes an annual loss of 974 million euros (12\% of annual university expenditure) (BBVA Foundation, 2019).

The methodology used was ex post facto, quantitative, with a descriptive and causal design.

From a total population of 477 students who started an undergraduate degree in the 2009/2010 - 2010/2011 entry cohort and failed to complete it, we randomly located $50 \%$ of the students who dropped out of each of the academic years that comprise it (first, second, third and fourth year). Thus, the resulting number of participants is 239. In order to summarize the sociological profile of these students, we present Table 1.

Table 1. Sociological profile of participants.

\begin{tabular}{lc}
\hline Variables & Prevailing value \\
\hline Sex & Female (75.3\%) \\
Marital status & Single $(85.7 \%)$ \\
Average age & $28.55(\mathrm{DS}=5.012)$ \\
Employment status & Active $(54.2 \%)$ \\
Place of residence & Seville $(73.3 \%)$ \\
Type of housing & Family $(60.8 \%)$ \\
Number of siblings & $1.66(\mathrm{DS}=1.385)$ \\
Parents' educational background & Primary $(36.6 \%)$ \\
Father's employment status & Active $(51.5 \%)$ \\
Mother's employment status & Inactive $(50.3 \%)$ \\
Parents' marital status & Married $(79,7 \%)$ \\
\hline
\end{tabular}

Source: own elaboration (2021).

An ad hoc questionnaire was used for data collection. A review of the bibliography served as a reference for its elaboration.

The SPSS v.22 statistical program was used to test the validity and reliability of the scales used. Reliability was estimated from Cronbach's alpha statistic, which provided an overall coefficient of 0.843 . The construct validity was performed by factor analysis, using the 
maximum likelihood procedure. The adequacy of this type of analysis is observed in Bartlett's test of sphericity, for each of the scales analyzed represents a degree of significance of 0.000 . Furthermore, these results are reinforced by the Kaiser-Meyer-Olkin test, which obtained values between 0.5 and 0.8 .

\section{Research results}

In response to our scientific objective, we present the personal and family variables associated with dropping out of a degree program. Specifically, we developed different hypothesis tests comparing the dependent variable "completion of university degree" with the independent variables "sex", "age", "marital status of students", "number of siblings" and "parents' educational background".

The Kolmogorov-Smirnow normality test allows us to test the significance of each of these variables $(\mathrm{p}>0.05)$, which do not follow a normal distribution.

Table 2. Kolmogorov-Smirnow normality test.

\begin{tabular}{lcc}
\hline Variables & Test statistics & Sig. \\
\hline Sex & .469 & .000 \\
Marital status & .500 & .000 \\
Average age & .280 & .000 \\
Number of siblings & .260 & .000 \\
Father's educational background & .255 & .000 \\
Mother's educational background & .282 & .000 \\
\hline
\end{tabular}

Source: own elaboration (2021).

Given the nature of the independent variables, we performed nonparametric tests using the Mann Whitney U test for two independent samples and the Kruskal-Wallis H test for more than two independent samples.

Before showing the results obtained in the hypothesis tests, it should be clarified that the hypotheses were formulated in the following terms:

- $\quad \mathrm{H}^{0}$ (null hypothesis): there are no significant differences between the completion of studies and the specific variables analyzed, with an alpha risk of error of $0.05 \%$.

- $\mathrm{H}^{1}$ (alternative hypothesis): there are significant differences between the completion of studies and the specific variables analyzed, with an alpha risk of error of $0.05 \%$. 
Table 3. $\mathbf{H}^{0}$ and $\mathbf{H}^{1}$ accepted in the different hypothesis tests.

\begin{tabular}{|c|c|c|c|c|c|}
\hline \multicolumn{2}{|c|}{ Relationship of variables } & \multicolumn{2}{|c|}{ Value } & \multirow{2}{*}{$\mathbf{p}$} & \multirow{2}{*}{$\begin{array}{l}\text { Accepted } \\
\text { hypothesis }\end{array}$} \\
\hline Dependent & Independent & $\mathbf{U}$ & $\mathbf{K}$ & & \\
\hline \multirow{6}{*}{$\begin{array}{l}\text { Completion of } \\
\text { university } \\
\text { degree }\end{array}$} & Sex & 435.000 & & .092 & $\mathrm{H}^{0}$ \\
\hline & Marital status & & 9.378 & .002 & $\mathrm{H}^{1}$ \\
\hline & Average age & & 7.522 & .006 & $\mathrm{H}^{1}$ \\
\hline & Number of siblings & & 8.293 & .004 & $\mathrm{H}^{1}$ \\
\hline & Father's educational background & & .136 & .712 & $\mathrm{H}^{0}$ \\
\hline & Mother's educational background & & .612 & .434 & $\mathrm{H}^{0}$ \\
\hline
\end{tabular}

Source: own elaboration (2021).

In Table 3, we observe that "age", "marital status of students" and "number of siblings" are associated with university dropout. Each of these variables obtains p-values lower than 0.05 . These results lead us to reject the null hypothesis and, consequently, to affirm the alternative hypothesis in each of the relationships.

On the other hand, there is no significant relationship between the dependent variable "completion of university degree" and the independent variables "sex" and "parents' educational blackground". These variables obtained p-values greater than 0.05 , allowing us to accept the null hypothesis in each of the relationships.

\section{Discussion and Conclusions}

The results obtained in this study allow us to identify personal and family variables associated with dropping out of university studies and to better understand the multidimensional nature of the dropout phenomenon. According to Belloc et al. (2010) or Lizarte Simon (2017), among others, students' university trajectory is affected by personal variables and variables related to the students' family and socioeconomic environment.

The hypothesis test shows that age and marital status are two personal variables associated with university dropout. According to García de Fanelli (2014) dropout substantially affects students over the age of 25 , since these students not only focus their attention on studying, but also working or taking care of the family. Although most of the students who drop out of the faculty under study are single, coinciding with Oloriz and Fernandez (2013), university dropout also affects other marital statuses, such as married or divorced.

Among the family variables associated with university dropout, the number of siblings the student stands out. Most of the participants in the study have a sibling, reaching a maximum 
of 10 in the family unit itself. This fact supports Rodriguez Urrego's (2019) assertion that the probability of dropping out increases, the greater the number of siblings in the family unit.

Parental educational background is not presented as a variable associated with university dropout. It would be convenient to study the collinearity effect between the variables marital status, mean age and number of siblings, as this effect could make parental educational background insignificant.

All considered, it is advisable to continue identifying variables associated with university degree completion, as well as investigating the different dropout situations. Using the perspective of the students themselves and contemplating essential elements of interaction generated between them and the context that triggers dropout, we will be able to know the effectiveness of certain mediating agents in the resolution of the problem of university dropout.

\section{References}

AIReF (2020). Estudio sistema universitario público andaluz. Retrieved from: https://tinyurl.com/y7gm2sav

Al Ghanboosi, S. \& Alqahtani, A. (2013). Student drop-out trends at Sultan Qaboos University and Kuwait University: 2000-2011. College Student Journal, 47 (3), 499-506.

Behr, A., Giese, M., Teguim Kamdjou, H.D. \& Theune, K. (2020). Dropping out of university: a literature review. Review of Education. An International Journal of Major Studies in Education, 8(2), 614-652. doi:10.1002/rev3.3202

Belloc, F., Maruotti, A. \& Petrella, L. (2010). University drop-out: an italian experience. Higher Education, 60 (2), 127-138. doi:10.1007/s10734-009-9290-1

Casquero, T. \& Navarro, M.L. (2010). Determinantes del abandono escolar temprano en España: Un análisis por género. Revista de Educación, (Número extraordinario), 191223.

Díaz Peralta, C. (2008). Modelo conceptual para la deserción estudiantil universitaria chilena. Estudios Pedagógicos, 34 (2), 62-86. doi:10.4067/S0718-07052008000200004

Eurostat. (2020). Tertiary education statistics. Retrieved from: https://tinyurl.com/yb4wa4up

Fonseca, G. \& García, F. (2016). Permanencia y abandono de estudios en estudiantes universitarios: un análisis desde la teoría organizacional. Revista de la Educación Superior, 45 (179), 25-39. doi:10.1016/j.resu.2016.06.004

BBVA Foundation. (2019). Indicadores Sintéticos de las Universidades Españolas. Retrieved from: https://www.fbbva.es/noticias/un-33-de-los-alumnos-no-finaliza-el-grado-queinicio-y-un-21-abandona-sin-terminar-estudios-universitarios/

Garbanzo Vargas, G.M. (2007). Factores asociados al rendimiento académico en estudiantes universitarios, una reflexión desde la calidad de la educación superior pública. Revista Educación, 31 (1), 43-63. doi:10.15517/REVEDU.V31I1.1252 
García de Fanelli, A.M. (2014). Rendimiento académico y abandono universitario. Modelos, resultados y alcances de la producción académica en la Argentina. Revista Argentina de Educación Superior, (8), 9-38.

González-Ramírez, T. \& Pedraza-Navarro, I. (2017). Variables sociofamiliares asociadas al abandono de los estudios universitarios. Educatio Siglo XXI, 35 (2), 365-388. doi: $10.6018 / \mathrm{j} / 298651$

Íñiguez, T., Elboj, C. \& Valero, D. (2016). La Universidad del Espacio Europeo de Educación Superior ante el abandono de los estudios de grado. Causas y propuestas estratégicas de prevención. Revista Educar, 52 (2), 285-313. doi:10.5565/rev/educar.674

Jara, D., Velarde, H., Gordillo, G., Guerra, G., León, I., Arroyo, C. \& Figueroa, M. (2008). Factores influyentes en el rendimiento académico de estudiantes del primer año de medicina. Anales de la Facultad de Medicina, 69 (3), 193-197. doi:10.15381/anales.v69i3.1140

Jones-White, D.R., Radcliffe, P.M., Lorenz, L.M. \& Soria, K.M. (2014). Price out? The influence of financial aid on the educational trajectories of first-year students starting college at a large research university. Research in Higher Education, 55 (4), 329-350. doi:10.1007/s11162-013-9313-8

Marchesi, A. (2000). Un sistema de indicadores de desigualdad educativa. Revista Iberoamericana de Educación, 23, 1-22.

MDSyF (2003). Encuesta CASEN. Retrieved from: http://observatorio.ministeriodesarrollosocial.gob.cl/casen/casen_obj.php

MICINN. (2020). Datos básicos del sistema universitario español: curso 2019-2020. Retrieved from: https://tinyurl.com/yc4rwfk6

OECD. (2019). Education at a Glance 2019. OECD Indicators. Retrieved from: https://doi.org/10.1787/f8d7880d-en

Ononye, L.C. \& Bong, S. (2018). The Study of the effectiveness of scholarship grant program on low-income engineering technology students. Journal of STEM Education: Innovations and Research, 18 (5), 26-31.

Patrick, M.E., Schulenberg, J.E. \& O’Malley, P.M. (2016). High school substance use as a predictor of collage attendance, completion, and dropout: a national multicohort longitudinal study. Youth \& Society, 48 (3), 425-447. doi:10.1177/0044118X13508961

Rodríguez-Pineda, M. \& Zamora-Araya, J.A. (2020). Abandono temprano en estudiantes universitarios: un estudio de cohorte sobre sus posibles causas. Uniciencia, 35 (1), 19-37. doi:10.15359/ru.35-1.2

Rodríguez Urrego, M. (2019). La investigación sobre deserción universitaria en Colombia 2006-2016. Tendencias y resultados. Pedagogía y Saberes, (51), 49-66.

Stoessel, K., Ihme, T. A., Barbarino, M. L., Fisseler, B. \& Stürmer, S. (2015). Sociodemografic diversity and distance education: who drops out from academic programs and why? Research in Higher Education, 56 (3), 228-246. doi:10.1007/s11162014-9343-X

Zanchin, M.L. (2017). Causas personales versus causas institucionales como motivo de deserción en el primer año de la carrera de Odontología de la Universidad Nacional de Rio Negro (Doctoral thesis). Universidad Internacional Iberoamericana, México. 